\title{
RISK ASSESSMENT PENYAKIT AKIBAT PAPARAN BAHAN KIMIA PADA UNIT PREMIX
}

\section{RISK ASSESSMENT OF DISEASES CAUSED BY CHEMICAL EXPOSURE AT PREMIX UNIT}

\author{
Rieneke Puspita Eka Suci \\ Magister Kesehatan dan Keselamatan Kerja \\ Fakultas Kesehatan Masyarakat, Universitas Airlangga \\ E-mail: rieneke.minam@gmail.com
}

\begin{abstract}
PT. Japfa Comfeed is one of poultry companies, in production of poultry needed feed additive to improve quality of poultry. Premix unit is unit that production feed additive for poultry. There are some hazards in process of premix production. Therefore, to prevent health problems, risk assessment is needed. The objective of this study is risk assessing at premix production PT. Japfa Comfeed Indonesia Tbk. Unit Gedangan. This research is a descriptive study. The population of this research were 15 person premix unit worker and 1 (one) safety officer at PT. Japfa Comfeed Indonesia Tbk. Unit Gedangan. The result of the research showed that there were chemical hazard, such as feed additives and meat and bone meal (MBM). Based on hazard identification obtained 34 risk with $76.5 \%$ medium risks and $23.5 \%$ low risks. Risk control on feed additive unit at PT. Japfa Comfeed Indonesia Tbk. Unit Gedangan was categorizes as good enough. This is due to risk control effort, such as engineering control, administrative control, and Personal Protective Equipment, such respiratory and glove. However, those efforts had not been fully applied by feed additive worker. Residual risk assessment showed that risk control needs to be reset to reduce the risk. Conclusion that can be drawn is process in premix unit categorized as medium risk.
\end{abstract}

Keywords: poultry, premix, risk assessment

\begin{abstract}
ABSTRAK
PT. Japfa Comfeed merupakan industri yang bergerak di bidang pakan ternak, dalam produksi pakan ternak dibutuhkan bahan tambahan untuk meningkatkan kualitas pakan ternak tersebut. Unit premix merupakan unit yang memproduksi bahan tambahan untuk pakan ternak. Dalam proses produksi premix, terdapat beberapa potensi bahaya yang berasal dari bahan tambahan. Oleh karena itu, untuk mencegah terjadinya gangguan kesehatan diperlukan adanya risk assessment. Tujuan penelitian ini adalah untuk melakukan risk assessment pada unit premix di PT. Japfa Comfeed Indonesia Tbk. Unit Gedangan. Penelitian ini termasuk penelitian deskriptif. Populasi dalam penelitian adalah 15 pekerja unit premix serta 1 orang safety officer di PT. Japfa Comfeed Indonesia Tbk. Unit Gedangan. Hasil penelitian menunjukkan bahwa terdapat kimia yang berasal dari bahan tambahan serta meat and bone meal (MBM). Hasil identifikasi memperoleh 34 risiko dengan $76,5 \%$ risiko sedang dan $23,5 \%$ risiko rendah. Sementara itu, pengendalian risiko yang ada tergolong cukup. Hal ini dikarenakan telah terdapat upaya pengendalian risiko meliputi pengendalian teknik, administratif, dan Alat Pelindung Diri, seperti masker dan sarung tangan. Akan tetapi, upaya pengendalian tersebut belum diterapkan sepenuhnya oleh pekerja unit premix. Penilaian risiko sisa menunjukkan bahwa diperlukan pertimbangan dalam implementasi pengendalian risiko. Kesimpulan yang dapat ditarik adalah pekerjaan di unit premix PT. Japfa Comfeed Indonesia Tbk. Unit Gedangan tergolong pekerjaan dengan risiko sedang.
\end{abstract}

Kata kunci: pakan ternak, premix, risk assessment

\section{PENDAHULUAN}

Industri pakan ternak merupakan salah satu industri yang sangat dibutuhkan untuk menunjang kegiatan peternakan di Indonesia. Dalam produksinya dibutuhkan beberapa bahan baku seperti biji jagung, tepung kedelai, tepung jagung, tepung daging dan tulang, serta bahan baku lainnya. Selain penggunaan bahan baku, produksi pakan ternak juga membutuhkan bahan premix. Premix adalah bahan campuran yang terdiri dari beberapa bahan feed additive yang telah diracik sesuai dengan formula. Feed additive sendiri merupakan bahan 
pakan tambahan yang diberikan pada ternak dengan tujuan meningkatkan produktivitas maupun kualitas produksi pada ternak (Murwani, dkk, 2002).

Risiko adalah kombinasi antara kemungkinan terjadinya suatu kejadian dan keparahan akibat potensi dari bahaya yang ada (ECAST, 2009). Setiap proses produksi yang ada pastinya akan menimbulkan risiko yang bisa berasal dari material, proses, maupun pekerja. Di PT. Japfa Comfeed Indonesia Tbk. Unit Gedangan pernah terjadi beberapa kecelakaan kerja. Data permasalahan yang ada pada PT. Japfa Comfeed Indonesia Tbk. Unit Gedangan dapat dilihat pada Tabel 1.

Proses produksi premix umumnya dapat menimbulkan risiko yang dapat menyebabkan kecelakaan kerja maupun penyakit akibat kerja. Proses produksi premix terdapat beberapa tahapan yaitu perencanaan produksi, penyusunan formula, peracikan, pengemasan, dan labelling.

Umumnya di dalam industri pakan ternak, banyak dihasilkan debu yang berasal dari feed additive maupun bahan baku lainnya. Berdasarkan penelitian yang dilakukan Lenhart, dkk. (2008) akibat paparan debu pada pekerja di industri pakan ternak, menyebabkan pekerja memiliki risiko lebih besar mengalami kerusakan pada sistem saluran pernafasan. Viegas (2013) menyebutkan bahwa paparan debu yang berasal dari sisa produk pakan ternak dapat menimbulkan asma, bronkitis kronik, PPOK, dan organic dust toxic syndrome (ODTS).

Bahan feed additive yang digunakan pada proses produksi premix di PT. Japfa Comfeed Indonesia Tbk. Unit Gedangan bermacam jenisnya, yaitu tepung batu $\left(\mathrm{CaCO}_{3}\right)$, monocalcium phosphate (MCP), garam ( $\mathrm{NaCl})$, L-lysine $\mathrm{HCl}$, Lysine sulphate, L-threonine, sodium bicarbonat, Copper sulfate, dan Choline $\mathrm{Cl}$. Umumnya, efek yang diakibatkan dari bahan-bahan tersebut berupa iritasi pada kulit, iritasi mata, gangguan pernafasan serta gangguan pencernaan serta ada bahan yang memiliki efek kronis. ATSDR (2004) berpendapat bahwa paparan dalam jangka panjang dan kadar yang berlebih dari copper sulfate dapat menimbulkan penyakit paru obstruktif kronik serta gangguan pada liver. Paparan bahan kimia tersebut merupakan salah satu bahaya yang dapat berisiko bagi pekerja.

International Labour Organization (ILO) menyatakan bahwa diperkirakan 2,3 juta pekerja meninggal setiap tahun akibat kecelakaan dan penyakit akibat kerja (PAK). Lebih dari 160 juta pekerja menderita penyakit akibat kerja dan 313 juta pekerja mengalami kecelakaan non-fatal per
Tabel 1. Data Permasalahan pada PT. Japfa Comfeed Indonesia Tbk. Unit Gedangan

\begin{tabular}{|c|c|c|}
\hline Bahaya & Risiko & Tingkat Risiko \\
\hline Debu jagung & $\begin{array}{l}\text { Gangguan saluran } \\
\text { pernafasan, sesak } \\
\text { nafas }\end{array}$ & Tinggi \\
\hline $\begin{array}{l}\text { Bahan feed } \\
\text { additive }\end{array}$ & $\begin{array}{l}\text { Iritasi kulit, iritasi } \\
\text { mata }\end{array}$ & Tinggi \\
\hline $\begin{array}{l}\text { Kebisingan di } \\
\text { atas NAB }\end{array}$ & $\begin{array}{l}\text { Ketulian, } \\
\text { pendengaran } \\
\text { berkurang }\end{array}$ & Tinggi \\
\hline $\begin{array}{l}\text { Tangan } \\
\text { tertusuk jarum } \\
\text { jahit }\end{array}$ & $\begin{array}{l}\text { Tangan terluka dan } \\
\text { berdarah }\end{array}$ & Sedang \\
\hline $\begin{array}{l}\text { Bekerja } \\
\text { dengan } \\
\text { membungkuk }\end{array}$ & Sakit punggung & Sedang \\
\hline $\begin{array}{l}\text { Tutup mesin } \\
\text { tidak rapat }\end{array}$ & $\begin{array}{l}\text { Jatuh, jari } \\
\text { kelingking pekerja } \\
\text { putus }\end{array}$ & Sedang \\
\hline $\begin{array}{l}\text { Tangan terjepit } \\
\text { penjepit } \\
\text { karung di unit } \\
\text { bagging }\end{array}$ & Tangan cidera & Rendah \\
\hline
\end{tabular}

Sumber: Kartikasari, 2012

tahunnya. Dari kasus tersebut 2,3 juta merupakan kasus fatality. Sekitar 651.279 diantaranya disebabkan oleh bahan kimia berbahaya (Kemenkes RI, 2014).

Keputusan Presiden No. 22 Tahun 1993, memaparkan bahwa paparan bahan kimia merupakan salah satu risiko yang paling banyak menimbulkan penyakit akibat kerja. Penelitian yang dilakukan oleh Gusani (2012) menunjukkan bahwa pemakaian bahan-bahan kimia tergolong ke dalam risiko tinggi selain dapat menyebabkan gangguan kesehatan terdapat beberapa bahan yang dapat menyebabkan kebakaran.

Pengendalian bahaya sangat penting untuk dilakukan di tempat kerja, agar dapat mengurangi timbulnya bahaya yang dapat mengganggu aktivitas produksi maupun pada tenaga kerja. Salah satu upaya yang diterapkan oleh perusahaan untuk meminimalkan risiko adalah diterapkannya risk assessment. Risk assessment adalah upaya yang dilakukan untuk menghitung besarnya suatu risiko dan menilai risiko tersebut dapat diterima atau tidak (OHSAS 18001: 2007). Terdapat beberapa metode dalam proses analisis risiko diantaranya adalah 
teknik kualitatif, semi kuantitatif, dan kuantitatif. Metode kualitatif merupakan pendekatan yang menggambarkan tingkat kemungkinan dan keparahan suatu kejadian dalam bentuk rentang dari risiko terendah sampai tertinggi. Metode ini dilakukan sebagai langkah awal untuk mengetahui risiko suatu kegiatan namun karena kurangnya penjelasan mengenai risiko terkadang beberapa pihak harus menerapkan sesuai presepsi masing-masing.

Data dari National Minerals Industry Safety and Health Risk Assessment dalam Kusuma (2013) menunjukkan analisis risiko yang dilakukan di pertambangan emas dapat menurunkan kasus kecelakaan kerja sekitar 50\%. Analisis risiko merupakan salah satu cara yang efektif untuk mengurangi terjadinya risiko kecelakaan kerja dan gangguan kesehatan yang ada pada pekerja unit premix. Tujuan dari penelitian ini adalah melakukan risk assessment pada unit premix di PT. Japfa Comfeed Indonesia Tbk.. Unit Gedangan dimulai dari identifikasi bahaya, penilaian risiko, menilai pengendalian bahaya, serta penilaian risiko sisa.

\section{METODE}

Penelitian ini berdasarkan sifatnya, penelitian ini termasuk dalam penelitian deskriptif yang memiliki tujuan memberikan gambaran objektif terhadap suatu keadaan dengan cara mendeskripsikannya. Penelitian ini termasuk dalam penelitian observasional, apabila ditinjau dari metode pengumpulan data. Penelitian ini berlokasi di PT. Japfa Comfeed Indonesia Tbk.. Unit Gedangan Jalan Raya Tebel KM 3.8 Gedangan, Sidoarjo, Jawa Timur pada tanggal 14-23 Mei 2017. Populasi penelitian ini adalah semua pekerja di bagian feed additive yang berjumlah 15 orang dan safety officer yang berjumlah 1 orang di PT. Japfa Comfeed Tbk. Unit Gedangan.

Variabel dalam penelitian ini adalah penilaian risiko (analisis likelihood dan analisis severity), penilaian pengendalian risiko, serta penilaian risiko sisa. Pengumpulan data dilakukan setelah responden diberi penjelasan mengenai Penjelasan Sebelum Persetujuan (PSP) dan informed consent.

Data yang dikumpulkan terdiri dari data primer dan data sekunder. Data primer dikumpulkan melalui dua cara yaitu melalui observasi dan wawancara. Observasi dilakukan secara langsung pada pekerja di unit premix di PT. Japfa Comfeed Indonesia Tbk. Unit Gedangan dan menggunakan lembar Job Safety Analysis (JSA). Wawancara dilakukan dengan beberapa pihak terkait yaitu pekerja di unit premix dan safety officer. Wawancara kepada pekerja unit premix dilakukan untuk memperoleh data terkait tahapan proses produksi premix serta bahaya yang ada di unit premix. Wawancara kepada safety officer dilakukan untuk memperoleh data terkait bahaya dan risiko di unit premix, serta pengendalian risiko yang telah dilakukan. Data sekunder diperoleh dari data perusahaan yang meliputi data tentang profil perusahaan, visi, misi, kebijakan K3, struktur organisasi, Standar Operasional Prosedur (SOP), dan catatan tentang unit premix.

Instrumen yang digunakan dalam pengumpulan data terdiri atas lembar observasi dan lembar wawancara. Pengumpulan data dengan observasi menggunakan lembar observasi berupa Job Safety Analysis (JSA). Hasil dari observasi dan wawancara selanjutnya akan dianalisis melalui beberapa tahapan, yaitu identifikasi bahaya, penilaian risiko (analisis likelihood dan analisis severity), pengendalian risiko, dan penilaian risiko sisa.

Tahapan awal dari risk assessment adalah identifikasi bahaya, pada tahapan ini setiap proses produksi di unit premix akan dilakukan pengidentifikasian bahaya. Pengumpulan data untuk identifikasi bahaya ini dilakukan dengan melakukan observasi dan wawancara.

Setelah dilakukan identifikasi bahaya, maka akan dilakukan penilaian risiko. Penilaian risiko akan dilakukan dengan metode kualitatif. Metode kualitatif merupakan pendekatan yang menggambarkan tingkat kemungkinan dan keparahan suatu kejadian dalam bentuk rentang dari risiko terendah sampai tertinggi. Matriks penilaian risiko terdapat pada Tabel 2 .

\section{HASIL}

\section{Pekerjaan Unit Premix di PT. Japfa Comfeed Indonesia Tbk. Unit Gedangan}

Pekerjaan yang dilakukan pada unit premix menggunakan berbagai macam bahan feed additive. Bahan feed additive terdiri dari tepung batu $\left(\mathrm{CaCO}_{3}\right)$, monocalcium phosphate ( $\mathrm{MCP})$, garam $(\mathrm{NaCl})$, L-lysine $\mathrm{HCl}$, lysine sulphate, l-threonine, sodium bicarbonat, copper sulfate, dan choline $\mathrm{Cl}$.

\section{Identifikasi Bahaya}

Hasil identifikasi didapatkan bahwa terdapat beberapa bahaya kimia yang berasal dari debu bahan feed additive yang digunakan maupun debu bahan baku. Feed additive yang digunakan 
Tabel 2. Matriks Penilaian Risiko

\begin{tabular}{lccccc}
\hline \multirow{2}{*}{ Likelihood } & \multicolumn{5}{c}{ Severity } \\
\cline { 2 - 6 } & $\begin{array}{c}\text { Insignificant } \\
\text { (1) }\end{array}$ & $\begin{array}{c}\text { Minor } \\
\mathbf{( 2 )}\end{array}$ & $\begin{array}{c}\text { Moderate } \\
\mathbf{( 3 )}\end{array}$ & $\begin{array}{c}\text { Major } \\
\mathbf{( 4 )}\end{array}$ & $\begin{array}{c}\text { Catastrophic } \\
\mathbf{( 5 )}\end{array}$ \\
\hline $\begin{array}{l}\text { Almost certain } \\
(5)\end{array}$ & $\mathrm{M}$ & $\mathrm{M}$ & $\mathrm{H}$ & $\mathrm{H}$ & $\mathrm{H}$ \\
\hline $\begin{array}{l}\text { Likely } \\
(4)\end{array}$ & $\mathrm{L}$ & $\mathrm{M}$ & $\mathrm{H}$ & $\mathrm{H}$ & $\mathrm{H}$ \\
\hline $\begin{array}{l}\text { Possible } \\
(3)\end{array}$ & $\mathrm{L}$ & $\mathrm{L}$ & $\mathrm{M}$ & $\mathrm{H}$ & $\mathrm{H}$ \\
\hline $\begin{array}{l}\text { Unlikely } \\
(2)\end{array}$ & $\mathrm{L}$ & $\mathrm{L}$ & $\mathrm{M}$ & $\mathrm{M}$ & $\mathrm{M}$ \\
\hline $\begin{array}{l}\text { Rare } \\
(1)\end{array}$ & $\mathrm{L}$ & $\mathrm{L}$ & $\mathrm{L}$ & $\mathrm{L}$ & $\mathrm{M}$ \\
\hline
\end{tabular}

Sumber: Standar AS/NZS 4360:2004

Tabel 3. Tingkat Risiko

\begin{tabular}{llc}
\hline \multicolumn{1}{c}{ Tingkat Risiko } & \multicolumn{1}{c}{ Tingkat Penerimaan Risiko } & Rating Risiko \\
\hline Risiko rendah (Low risk) & Dapat diterima (Generally acceptable) & $1-4$ \\
Risiko sedang (Medium risk) & Risiko dapat ditolerir (Tolerable) & $5-10$ \\
Risiko tinggi (High risk) & Tidak dapa diterima (Generally unacceptable) & $12-25$ \\
\hline
\end{tabular}

Sumber: Standar AS/NZS 4360:2004

dalam proses produksi ini bermacam-macam, yaitu tepung batu $\left(\mathrm{CaCO}_{3}\right)$, monocalcium phosphate (MCP), L-lysine $\mathrm{HCl}$, lysine sulphate, l-threonine, sodium bicarbonate, copper sulfate, dan choline chloride. Dampak yang diakibatkan oleh bahan tersebut bermacam-macam, yaitu iritasi kulit, iritasi mata, iritasi saluran pernafasan, gangguan saluran pencernaan, gangguan pada sistem metabolisme, gangguan pada paru, sistem kardiovaskuler, dan sistem saraf.

\section{Penilaian Risiko}

Langkah selanjutnya yang dilakukan sesudah identifikasi bahaya ialah penilaian risiko. Penilaian risiko dilakukan dengan mempertimbangkan nilai likelihood dan severity suatu risiko. Hasil penilaian risiko dapat dilihat pada Tabel 4.

\section{Pengendalian Risiko}

Hasil penilaian risiko yang tinggi memerlukan suatu pengendalian untuk menurunkan risiko sampai batas aman. Pengendalian yang sudah dilakukan pada unit premix PT. Japfa Comfeed Indonesia Tbk. Unit Gedangan, yaitu pengendalian teknis, pengendalian administratif, serta Alat Pelindung Diri (APD).

Pengendalian teknis adalah pengendalian bahaya melalui perbaikan pada desain, penambahan peralatan, serta pemasangan peralatan pengamanan. Pengendalian teknis yang telah dilakukan di unit premix adalah pemasangan exhaust fan yang bertujuan untuk menurunkan kadar pencemaran agar siskulasi udara di ruang kerja tetap terjaga sehingga udara di ruang kerja tetap sehat. Pengendalian administratif merupakan pengendalian yang menggunakan sistem atau panduan untuk melakukan pengendalian terhadap risiko.

Pengendalian administrasi yang telah dilakukan pada unit premix, yaitu pelatihan K3, adanya SOP dalam pekerjaan di unit premix, rotasi kerja, serta pengukuran udara secara berkala. Perusahaan melakukan pengendalian terakhir yaitu dengan penggunaan Alat Pelindung Diri (APD) untuk tiap pekerja di unit premix, yaitu sepatu, masker, dan sarung tangan. 
Tabel 4. Penilaian Risiko pada Unit Feed Additive PT. Japfa Comfeed Indonesia Tbk. Unit Gedangan Tahun 2017

\begin{tabular}{|c|c|c|c|c|c|}
\hline \multirow{2}{*}{ Proses } & \multirow{2}{*}{ Potensi Bahaya } & \multirow{2}{*}{ Risiko } & \multicolumn{3}{|c|}{ Tingkat Risiko } \\
\hline & & & $\mathbf{L}$ & $\mathbf{S}$ & Level of Risk \\
\hline \multirow{35}{*}{$\begin{array}{l}\text { Peracikan } \\
\text { premix }\end{array}$} & \multicolumn{5}{|c|}{ Debu bahan feed additive: } \\
\hline & \multirow{3}{*}{ Tepung batu $\left(\mathrm{CaCO}_{3}\right)$} & Iritasi kulit & 4 & 2 & 8 (medium risk) \\
\hline & & Iritasi mata & 2 & 2 & $4($ low risk) \\
\hline & & Iritasi saluran pernafasan & 4 & 2 & $8($ medium risk $)$ \\
\hline & \multirow{4}{*}{$\begin{array}{l}\text { Monocalcium } \\
\text { phospate (MCP) }\end{array}$} & Iritasi mata & 3 & 2 & $6($ medium risk $)$ \\
\hline & & Iritasi kulit & 2 & 2 & $4($ low risk $)$ \\
\hline & & $\begin{array}{l}\text { Iritasi hidung dan tenggorokan, serta } \\
\text { nyeri dada }\end{array}$ & 4 & 2 & $8($ medium risk) \\
\hline & & Nyeri pada perut, mual dan diare & 3 & 2 & 6(medium risk) \\
\hline & \multirow[t]{4}{*}{ L-lysine $\mathrm{HCl}$} & Iritasi mata & 2 & 2 & $4($ low risk $)$ \\
\hline & & Iritasi kulit & 2 & 2 & $4($ low risk $)$ \\
\hline & & Iritasi saluran pernafasan & 4 & 2 & $8($ medium risk) \\
\hline & & Gangguan pada lambung & 3 & 2 & 6(medium risk) \\
\hline & Lysine sulphate & Iritasi kulit & 3 & 2 & 6(medium risk) \\
\hline & \multirow[t]{3}{*}{ L-threonine } & Iritasi kulit & 2 & 2 & $4($ low risk $)$ \\
\hline & & Iritasi saluran pencernaan & 3 & 2 & $6($ medium risk) \\
\hline & & Iritasi saluran pernafasan & 3 & 2 & $6($ medium risk $)$ \\
\hline & \multirow[t]{7}{*}{ Sodium bicarbonat } & Iritasi mata & 3 & 2 & $6($ medium risk $)$ \\
\hline & & Iritasi kulit & 2 & 2 & $4($ low risk $)$ \\
\hline & & Iritasi saluran pernafasan & 4 & 2 & $8($ medium risk) \\
\hline & & Gangguan pada saluran pencernaan & 3 & 2 & $6($ medium risk $)$ \\
\hline & & Gangguan pada sistem metabolisme & 2 & 3 & $6($ medium risk) \\
\hline & & $\begin{array}{l}\text { Gangguan pada sistem } \\
\text { kardiovaskuler }\end{array}$ & 2 & 3 & 6(medium risk) \\
\hline & & Gangguan pada sistem saraf & 2 & 4 & 8 (medium risk) \\
\hline & \multirow[t]{6}{*}{ Copper sulfate } & Nyeri pada perut, mual, dan, diare & 3 & 3 & $9($ medium risk) \\
\hline & & $\begin{array}{l}\text { Iritasi mata, kemerahan, panas, dan } \\
\text { pandangan buram }\end{array}$ & 3 & 2 & 6(medium risk) \\
\hline & & $\begin{array}{l}\text { Iritasi saluran pernafasan, batuk dan } \\
\text { luka pada tenggorokan }\end{array}$ & 4 & 2 & $8($ medium risk) \\
\hline & & Gangguan pada paru & 3 & 3 & 9 (medium risk) \\
\hline & & Iritasi kulit, kemerahan, dan nyeri & 3 & 2 & $6($ medium risk $)$ \\
\hline & & $\begin{array}{l}\text { Gangguan pada peredaran darah, } \\
\text { ginjal dan hati }\end{array}$ & 2 & 4 & $8($ medium risk) \\
\hline & \multirow[t]{2}{*}{ Choline $\mathrm{Cl}$} & Iritasi kulit & 2 & 2 & $4($ low risk) \\
\hline & & Iritasi saluran pernafasan & 3 & 2 & $6($ medium risk $)$ \\
\hline & \multirow{4}{*}{$\begin{array}{l}\text { Debu bahan baku } \\
\text { (Meat and Bone Meal) }\end{array}$} & Iritasi kulit & 2 & 2 & $4($ low risk) \\
\hline & & Iritasi mata & 3 & 2 & $6($ medium risk $)$ \\
\hline & & Iritasi saluran pencernaan & 2 & 3 & $6($ medium risk) \\
\hline & & Iritasi saluran pernafasan & 4 & 2 & 8(medium risk) \\
\hline
\end{tabular}


Tabel 5. Penilaian Risiko Sisa Unit Premix PT. Japfa Comfeed Indonesia Tbk. Unit Gedangan Tahun 2017

\begin{tabular}{|c|c|c|c|c|c|}
\hline Proses & $\begin{array}{l}\text { Potensi } \\
\text { Bahaya }\end{array}$ & Risiko & Level of Risk & $\begin{array}{c}\text { Risk } \\
\text { Control }\end{array}$ & $\begin{array}{l}\text { Residual } \\
\text { Risk }\end{array}$ \\
\hline \multirow{35}{*}{$\begin{array}{l}\text { Peracikan } \\
\text { premix }\end{array}$} & \multicolumn{5}{|c|}{ Debu bahan feed additive: } \\
\hline & \multirow{3}{*}{$\begin{array}{l}\text { Tepung batu } \\
\left(\mathrm{CaCO}_{3}\right)\end{array}$} & Iritasi kulit & 8 (medium risk) & $65 \%$ & 3 (low risk) \\
\hline & & Iritasi mata & 4 (low risk) & $50 \%$ & $\begin{array}{l}2(\text { low } \\
\text { risk })\end{array}$ \\
\hline & & Iritasi saluran pernafasan & 8 (medium risk) & $65 \%$ & $3($ low risk) \\
\hline & \multirow{4}{*}{$\begin{array}{l}\text { Monocalcium } \\
\text { phospate } \\
\text { (MCP) }\end{array}$} & Iritasi mata & 6 (medium risk) & $50 \%$ & $3($ low risk $)$ \\
\hline & & Iritasi kulit & 4 (low risk) & $65 \%$ & 1 (low risk) \\
\hline & & Iritasi hidung dan tenggorokan, serta nyeri dada & 8 (medium risk) & $65 \%$ & $3($ low risk) \\
\hline & & Nyeri pada perut, mual dan diare & 6 (medium risk) & $75 \%$ & $2($ low risk $)$ \\
\hline & \multirow[t]{4}{*}{ L-lysine $\mathrm{HCl}$} & Iritasi mata & 4 (low risk) & $50 \%$ & $2($ low risk $)$ \\
\hline & & Iritasi kulit & 4 (low risk) & $65 \%$ & 1 (low risk) \\
\hline & & Iritasi saluran pernafasan & 8 (medium risk) & $65 \%$ & $3($ low risk) \\
\hline & & Gangguan pada lambung & 6 (medium risk) & $75 \%$ & $2($ low risk) \\
\hline & $\begin{array}{l}\text { Lysine } \\
\text { sulphate }\end{array}$ & Iritasi kulit & 6 (medium risk) & $65 \%$ & $2($ low risk $)$ \\
\hline & \multirow[t]{3}{*}{ L-threonine } & Iritasi kulit & 4 (low risk) & $65 \%$ & 1 (low risk) \\
\hline & & Iritasi saluran pencernaan & 6 (medium risk) & $75 \%$ & $2($ low risk) \\
\hline & & Iritasi saluran pernafasan & 6 (medium risk) & $65 \%$ & $2($ low risk) \\
\hline & \multirow{7}{*}{$\begin{array}{l}\text { Sodium } \\
\text { bicarbonat }\end{array}$} & Iritasi mata & 6 (medium risk) & $50 \%$ & $3($ low risk) \\
\hline & & Iritasi kulit & 4 (low risk) & $65 \%$ & $1($ low risk) \\
\hline & & Iritasi saluran pernafasan & 8 (medium risk) & $65 \%$ & $3($ low risk) \\
\hline & & Gangguan pada saluran pencernaan & 6 (medium risk) & $75 \%$ & $2($ low risk) \\
\hline & & Gangguan pada sistem metabolisme & 6 (medium risk) & $75 \%$ & $2($ low risk) \\
\hline & & Gangguan pada sistem kardiovaskuler & 6 (medium risk) & $75 \%$ & $2($ low risk) \\
\hline & & Gangguan pada sistem saraf & 8 (medium risk) & $75 \%$ & $2($ low risk) \\
\hline & \multirow{6}{*}{$\begin{array}{l}\text { Copper } \\
\text { sulfate }\end{array}$} & Nyeri pada perut, mual, dan diare & 9 (medium risk) & $75 \%$ & $2($ low risk) \\
\hline & & $\begin{array}{l}\text { Iritasi mata, kemerahan, panas, dan pandangan } \\
\text { buram }\end{array}$ & 6 (medium risk) & $50 \%$ & $3($ low risk) \\
\hline & & $\begin{array}{l}\text { Iritasi saluran pernafasan, batuk dan luka pada } \\
\text { tenggorokan }\end{array}$ & 8 (medium risk) & $65 \%$ & $3($ low risk) \\
\hline & & Gangguan pada paru & 9 (medium risk) & $65 \%$ & $3($ low risk) \\
\hline & & Iritasi kulit, kemerahan, dan nyeri & 6 (medium risk) & $65 \%$ & $2($ low risk) \\
\hline & & Gangguan pada peredaran darah, ginjal dan hati & 8 (medium risk) & $75 \%$ & $2($ low risk) \\
\hline & \multirow[t]{2}{*}{ Choline $\mathrm{Cl}$} & Iritasi kulit & 4 (low risk) & $65 \%$ & $1($ low risk) \\
\hline & & Iritasi saluran pernafasan & 6 (medium risk) & $65 \%$ & $2($ low risk) \\
\hline & \multirow{4}{*}{$\begin{array}{l}\text { Debu bahan } \\
\text { baku } \\
\text { (Meat and } \\
\text { Bone Meal) }\end{array}$} & Iritasi kulit & 4 (low risk) & $65 \%$ & $1($ low risk $)$ \\
\hline & & Iritasi mata & 6 (medium risk) & $50 \%$ & $3($ low risk) \\
\hline & & Iritasi saluran pencernaan & 6 (medium risk) & $75 \%$ & $2($ low risk $)$ \\
\hline & & Iritasi saluran pernafasan & 8 (medium risk) & $65 \%$ & $3($ low risk) \\
\hline
\end{tabular}




\section{Penilaian Risiko Sisa}

Hasil penilaian risiko dan pengendalian risiko pada unit premix di PT. Japfa Comfeed Indonesia Tbk. Unit Gedangan diketahui bahwa setelah dilakukan beberapa upaya pengendalian, masih ada beberapa risiko sisa yang masuk ke dalam kategori low risk yang artinya pengendalian tambahan tidak diperlukan.

Hal yang perlu diperhatikan adalah jalan keluar yang lebih menghemat biaya atau peningkatan yang tidak memerlukan tambahan besar. Pemantauan diperlukan untuk memastikan bahwa pengendalian dipelihara dan ditetapkan dengan baik dan benar. Selain itu, nilai risiko sisa yang ada di unit premix di PT. Japfa Comfeed Indonesia Tbk. Unit Gedangan umumnya lebih dari satu sehingga diharapkan adanya pertimbangan dalam proses pengendalian risiko di unit tersebut.

\section{PEMBAHASAN}

\section{Identifikasi Bahaya}

Identifikasi bahaya merupakan langkah pertama yang dilakukan untuk mengetahui bahaya apa saja yang ditimbulkan dari segala aktivitas pekerjaan yang ada di unit premix PT. Japfa Comfeed Indonesia Tbk. Unit Gedangan. Upaya ini dilakukan bertujuan untuk mengenal berbagai bahaya kimia dan risiko yang memungkinkan di lingkungan kerja. Identifikasi bahaya ini dilakukan dengan mengidentifikasi bahaya yang ada pada setiap langkah kerja di unit premix menggunakan lembar Job Safety Analysis (JSA).

Identifikasi bahaya yang dilakukan menemukan beberapa bahaya kimia yang berasal pada proses peracikan di unit premix PT. Japfa Comfeed Indonesia Tbk. Unit Gedangan. Bahaya kimia ini berasal dari bahan feed additive yang digunakan pada proses peracikan premix. Jenis bahan feed additive yang digunakan bermacam, yang artinya sifat tiap bahan pun berbeda sehingga risiko yang ditimbulkan pun bermacam pula. Risiko yang ditimbulkan pun ada yang hanya mengakibatkan gangguan kesehatan ringan ada pula yang dapat menyebabkan penyakit kronis. Misalnya saja, penggunaan lisin sulfat apabila dalam waktu yang lama dapat menimbulkan risiko terjadinya iritasi kulit. Pekerja terpapar copper sulfate dalam periode yang lama maka pekerja berisiko mengalami Penyakit Paru Obstruktif Kronis (PPOK). Selain itu, bahan baku yang disimpan di dekat unit premix juga dapa menimbulkan bahaya bagi pekerja di unit tersebut. Bahan baku tersebut merupakan bahan baku meat and bone meal (MBM). Bahan baku tersebut berisiko menyebabkan gangguan kesehatan bagi pekerja, namun umumnya gangguan tersebut baru muncul apabila pekerja terpapar dalam waktu yang lama. Risiko yang dapat ditimbulkan dari bahan tersebut adalah iritasi kulit, iritasi mata, iritasi saluran pencernaan, dan iritasi saluran pernafasan.

\section{Penilaian Risiko}

Tahapan berikutnya adalah penilaian risiko. Hasil penelitian menunjukkan adanya 34 macam risiko yang ada pada unit premix PT. Japfa Comfeed Indonesia Tbk. Unit Gedangan. Penilaian risiko dilakukan dengan cara memberikan nilai terhadap kemungkinan (likelihood) dan keparahan (severity) dari setiap risiko yang telah teridentifikasi. Standar yang digunakan dalam penilaian risiko merupakan AS/NZS 4360:2004 dan penilaian risiko yang dilakukan bersifat kualitatif.

Salah satu potensi bahaya kimia yang ada pada proses peracikan adalah terpapar debu copper sulfate. Debu tersebut dapat masuk ke dalam tubuh kerja melalui inhalasi, ingesti, serta kontak dengan kulit. Copper sulfate memiliki sifat iritan, artinya apabila pekerja terpapar maka dapat menyebabkan iritasi pada organ tubuh yang terpapar seperti iritasi pada saluran pernafasan, saluran pencernaan, mata serta kulit. Selain risiko terjadinya iritasi, paparan copper sulfate yang berlangsung lama dapat menyebabkan terjadinya gangguan pada paru maupun hati (ATSDR, 2004). Paparan melalui inhalasi dengan jangka waktu yang lama berpotensi menyebabkan terjadinya Penyakit Paru Obstruktif Kronik (PPOK). Penyakit ini menyebabkan terjadinya penyempitan pada saluran pernafasan yang dapat disebabkan oleh terjadinya iritasi dan inflamasi pada lapisan saluran pernafasan yang menyebabkan adanya pembengkakan pada lapisan dan produksi mukus yang berlebihan, serta adanya kerusakan pada dinding alveolus. Gangguan pada hati juga dapat terjadi apabila copper sulfate masuk ke dalam tubuh melalui ingesti dengan kadar yang berlebihan dalam jangka waktu yang lama.

Risiko terjadinya PPOK yang disebabkan oleh debu copper sulfate ketika dalam proses peracikan severity-nya diberikan nilai 3. Sedangkan untuk nilai likelihood-nya diberikan nilai 3 karena sifat copper sulfate yang tidak toksik serta tersedianya APD bagi pekerja berupa sarung tangan dan masker yang dikenakan ketika bekerja. Sehingga risiko terjadinya 
PPOK akibat paparan copper sulfate termasuk ke dalam kategori risiko sedang dengan nilai 9. Selain itu, risiko terjadinya Iritasi mata, kemerahan, panas, dan pandangan buram yang diakibatkan copper sulfate nilai severity-nya adalah 2. Nilai yang diberikan untuk likelihood-nya adalah 3, hal ini dikarenakan sifat copper sulfate yang iritan namun tersedianya pengendalian berupa SOP. Sehingga risiko terjadinya iritasi mata akibat paparan copper sulfate termasuk ke dalam kategori sedang dengan nilai 6 .

Debu bahan baku MBM dapat menimbulkan iritasi kulit, iritasi mata, iritasi saluran pernafasan, dan iritasi saluran pencernaan. Potensi iritasi kulit akibat paparan debu MBM diberi nilai severity2, dikarenakan keparahan yang ditimbulkan hanya berdampak ringan. Nilai likelihood-nya adalah 2 hal ini dikarenakan tersedianya pengendalian berupa SOP serta kebijakan penggunaan APD berupa sarung tangan.

Hasil dari penilaian risiko yang telah dilakukan menunjukkan sebesar 26 risiko (76,5\%) termasuk dalam kategori risiko sedang dan 8 risiko $(23,5 \%)$ adalah risiko rendah. Risiko yang ada pada pekerjaan di unit premix termasuk ke dalam kategori sedang. Bila risiko tersebut masuk ke dalam risiko sedang, artinya perlu adanya tindakan yang dilakukan untuk mengurangi risiko tetapi biaya pencegahan yang diperlukan harus diperhitungkan dengan teliti dan dibatasi. Pengukuran pengurangan risiko perlu diterapkan dengan baik dan benar.

\section{Pengendalian Risiko}

Pengendalian risiko merupakan tahapan selanjutnya setelah diketahui risiko yang ada dari suatu pekerjaan. Segala risiko yang telah teridentifikasi maka harus dikendalikan, terutama jika risiko tersebut termasuk ke dalam kategori risiko tinggi. OHSAS 18001 menyebutkan apabila terdapat beberapa pengendalian risiko yaitu, eliminasi, substitusi, rekayasa teknik, administrasi, dan APD.

PT. Japfa Comfeed Indonesia Tbk. Unit Gedangan telah melakukan beberapa pengendalian risiko, mulai dari pengendalian teknik, administasi, serta alat pelindung diri. Pengendalian teknik yang telah dilakukan pada unit premix adalah adanya pemasangan exhaust fan. Pengendalian administrasi pada unit tersebut adalah pelatihan $\mathrm{K} 3$, tersedianya SOP, rotasi kerja tiap 1 minggu sekali, dan dilakukan pengukuran udara secara berkala. Pengendalian terakhir yaitu dengan penggunaan Alat Pelindung
Diri untuk tiap pekerja di unit premix, yaitu sepatu, masker dan sarung tangan.

Potensi risiko terjadinya iritasi mata akibat sodium bicarbonat tegolong ke dalam risiko sedang, sehingga diperlukan adanya pengendalian. Pengendalian yang telah dilakukan untuk mencegah risiko terjadinya iritasi mata adalah adanya SOP dengan nilai pengendalian $50 \%$. Pemberian nilai tersebut dikarenakan pengendalian yang ada dirasa masih kurang efektif. Potensi risiko terjadinya iritasi kulit dikendalikan dengan adanya SOP serta penggunaan APD berupa sarung tangan. Pengendalian tersebut diberi skor $65 \%$, dikarenakan pengendalian sudah sesuai namun dalam implementasinya masih banyak pekerja yang tidak mau menggunakan sarung tangan. Potensi risiko yang lainnya adalah terjadinya iritasi saluran pencernaan. Pengendalian yang telah dilakukan adalah penggunaan APD berupa masker dan sarung tangan. Pengendalian ini diberi nilai $75 \%$, karena dianggap sudah efisien untuk mengurangi terjadinya risiko tersebut tetapi masih perlu ditingkatkan kembali.

Umumnya, pengendalian risiko pada unit premix PT. Japfa Comfeed Indonesia Tbk. Unit Gedangan sudah diimplementasikan dengan baik. Masih ada beberapa pengendalian yang dirasa masih kurang optimal. Misalnya, penggunaan APD seperti masker dan sarung tangan. Di lapangan, masih banyak pekerja yang enggan menggunakan APD ketika proses peracikan sedang berlangsung dikarenakan rasa kurang nyaman serta masih adanya anggapan bahwa apabila menggunakan APD maka pekerja akan sulit untuk memenuhi target yang ditentukan. Pemilihan masker yang digunakan pun tidak sesuai dengan jenis bahaya yang ada di unit premix diharapkan ke depan akan ada perbaikan untuk penggunaan APD. Hal itu dikarenakan penggunaan respirator yang sesuai akan membantu menurunkan risiko terkena gangguan saluran pernafasan (Kearney, dkk., 2014).

\section{Penilaian Risiko Sisa}

Tahapan risk assessment yang terakhir adalah penilaian risiko sisa. Risiko sisa merupakan risiko yang masih mungkin ada setelah dilakukannya pengendalian (Siswanto, 2009). Ramli (2010) memaparkan bahwa pengendalian risiko tidak mungkin akan menghilangkan $100 \%$ bahaya atau risiko di lingkungan kerja. Faktor yang menyebabkan masih adanya risiko sisa pada lingkungan kerja, yaitu adanya subjektivitas di dalam penentuan besarnya 
kemungkinan dan dampak terjadinya suatu risiko, serta memprioritaskan seluruh risiko.

Hasil dari penilaian risiko sisa yang mendapat skor 0 maka termasuk ke dalam kategori no risk, artinya tidak adanya keraguan terhadap pengendalian. Bila skor penilaian risiko sisa adalah 1-4 maka termasuk ke dalam kategori low risk, artinya pengendalian tambahan tidak diperlukan hanya saja diperlukan pemilihan pengendalian yang dapat menghemat biaya. Kategori medium risk adalah kategori risiko sisa mendapatkan skor 5-9, artinya diperlukan tindakan tambahan namun perlu diperhatikan juga biayanya. Skor 10-16 tergolong ke dalam kategori high risk, artinya perlu dilakukan tindakan segera. Kategori terakhir adalah extreme risk dengan skor 20-25, artinya pekerjaan tidak boleh dilanjutkan.

Tabel 5 menunjukkan bahwa semua risiko yang ada pada unit premix PT. Japfa Comfeed Indonesia Tbk. Unit Gedangan termasuk ke dalam kategori low risk, artinya pengendalian tambahan tidak diperlukan. Hal yang perlu diperhatikan adalah jalan keluar yang lebih menghemat biaya atau peningkatan yang tidak memerlukan tambahan besar. Pemantauan diperlukan untuk memastikan bahwa pengendalian dipelihara dan ditetapkan dengan baik dan benar (Siswanto, 2009). Ramli (2010) berpendapat jika nilai risiko sisa lebih dari satu, maka pengendalian perlu dipertimbangkan dengan strategi yang lebih baik.

\section{SIMPULAN}

Hasil identifikasi bahaya yang telah dilakukan pada unit premix PT. Japfa Comfeed Indonesia Tbk. Unit Gedangan, menunjukkan bahwa terdapat 34 risiko yang berasal dari bahan feed additive dan bahan baku MBM. Hasil penilaian risiko di unit premix PT. Japfa Comfeed Indonesia Tbk. Unit Gedangan didapatkan 26 risiko (76,5\%) termasuk dalam kategori risiko sedang dan 8 risiko $(23,5 \%)$ adalah risiko rendah.

Pengendalian risiko pada unit premix PT. Japfa Comfeed Indonesia Tbk. Unit Gedangan yaitu dengan cara pengendalian teknik, administrasi, serta alat pelindung diri. Pengendalian teknik yang telah dilakukan pada unit premix adalah adanya pemasangan exhaust fan. Pengendalian administrasi pada unit tersebut adalah pelatihan $\mathrm{K} 3$, tersedianya SOP, rotasi kerja tiap 1 minggu sekali, dan dilakukan pengukuran udara secara berkala. Pengendalian terakhir yaitu dengan penggunaan Alat Pelindung
Diri untuk tiap pekerja di unit premix, yaitu sepatu, masker, dan sarung tangan.

Penilaian pengendalian risiko pada unit premix PT. Japfa Comfeed Indonesia Tbk. Unit Gedangan, diketahui bahwa termasuk ke dalam kategori yang cukup baik. Hal tersebut dikarenakan jenis pengendalian yang telah diterapkan cukup sesuai dan pengimplementasiannya pun sudah cukup.

Penilaian risiko sisa pada unit premix PT. Japfa Comfeed Indonesia Tbk. Unit Gedangan, diketahui bahwa semua risiko yang ada pada unit premix PT. Japfa Comfeed Indonesia Tbk. Unit Gedangan termasuk ke dalam kategori low risk, artinya pengendalian tambahan tidak diperlukan. Nilai risiko sisa lebih dari satu, maka pengendalian perlu dipertimbangkan dengan strategi yang lebih baik.

\section{DAFTAR PUSTAKA}

Agency for Toxic Substances and Disease Registry., 2004. Public Health Statement for Copper. [online] Tersedia di: www.atsdr.cdc.gov/ToxProfiles/ TP.asp?id=206\&tid=37. [diakses 4Juni 2017].

Australian/New Zealand Standard., 2004. AS/NZS 4360:Risk Management Guidelines. Sidney: Australia/New Zealand Standards.

European Commercial Aviation Safety Team., 2009. Safety Management System and Safety Culture Working Group - Guidance on Hazard Identification. ESSI.

Gusani, D., 2012. Analisis Risiko Keselamatan dan Kesehatan Kerja di Penyamakan Kulit X Tahun 2012. Skripsi. Jakarta: Universitas Indonesia.

Kartiksaari, N., 2012. Risk Assessment pada Bagian Produksi Unit Bagging PT. Japfa Comfeed Indonesia Tbk. Unit Gedangan. Skripsi. Surabaya: Universitas Airlangga.

Kearney, G., Shaw, R., dan Marcom, R., 2014. Evaluation of Respiratory Symptoms and Respiratory Protection Behavior Among Poultry Workers in Small Farming Operations. Journal of Agromedecine, vol. 19, pp. 162-170.

Kementerian Kesehatan RI., 2014. Tersedia di: $<$ www.depkes.go.id $>$ [diakses 29 Oktober 2016]

Keputusan Presiden No. 22 Tahun 1993 Tentang Penyakit yang Timbul Karena Hubungan Kerja. Jakarta: Presiden Republik Indonesia.

Kusuma, H., 2013. Risk Assessment pada Pekerjaan Overhaul Pembersihan Boiler Bagian Furnace di PT. PJB Gresik. Skripsi. Surabaya: Fakultas Kesehatan Masyarakat Universitas Airlangga. 
Lenhart, S., Morris, P., Akin, R., Olenchock, S., Service, W., dan Boone, W., 1990. Organic Dust, Endotoxin, and Ammonia Exposures in the North Carolina Poultry Processing Industry. Journal of Applied Occupational and Environmental Hygiene, vol. 5, pp. 611-618.

Murwani, R., C.I. Sutrisno, Endang K., Tristiarti dan Fajar W., 2002. Kimia dan Toksikologi Pakan. Semarang: Diktat Kuliah Kimia dan Toksiologi Pakan.

Occupational Health and Safety Assessment Series 18001., 2007. Occupational Health and Safety Management System-Requirement. British Standards.
Ramli, S., 2010. Pedoman Praktis Manajemen Risiko dalam Perspektif K3 OHS Risk Management. Jakarta: Dian Rakyat.

Siswanto., 2009. Risk Assessment. Surabaya: Balai Hiperkes dan Keselamatan Kerja.

Viegas, S., Faisca, V., Dias, H., Clerigo, A., Carolino, E., dan Viegas, C., 2013. Occupational Exposure to Poultry Dust and Effects on the Respiratory System in Workers. Journal of Toxicology and Environmental Health, Part A, Vol. 76, pp. 230-239. 